\title{
THE NORM AND ITS DEVIATIONS IN THE CONTEXT OF CHILDHOOD SEMIOTICS: THE BELARUS TRADITION AGAINST THE SLAVONIC BACKGROUND
}

\author{
Tatsiana Valodzina \\ Center for Belarusian Culture, Language and Literature Research \\ National Academy of Sciences, Belarus \\ e-mail: tanja_volodina@tut.by
}

\begin{abstract}
The article is dedicated to the study of early childhood in the context of ideas about its standard flow and deviations which are logical from the point of view of childhood mythology. Infancy in traditional spiritual culture is presented as a rather long period of transition, the period when the child is gradually freed from 'chaotic' signs, overcomes other-worldly influences, the human face of the child is finally appearing, and he or she is finally affirmed as a full-fledged member of society. Infantile diseases appear as the phenomenon stimulated by the very fact of birth and, along with that, a marker of the natural in the human body. Their overcoming becomes one more step on the way to maturing and socialization of a small human being. Child's health in folk representations directly depends on correct (re)distribution of the lot (possessions) both among people and nonhuman residents of the estate. Folklore texts and rituals from early childhood recreate archaic understanding of health as a part of the overall lot. The article is based on the materials of the late nineteenth - early twenty-first centuries: of importance here are the author's records made under a special program in expeditions to Belarusian villages over the last fifteen years.
\end{abstract}

Keywords: Belarus, childhood semiotics, deviations, folklore texts, folk medicine, incantations, transitional ritual

The topicality of the research is stipulated by the absence of generalizing papers dealing with characteristics of healing practices in childhood ethnosemiotics; fragmentary description of folk medicine as an ethnocultural complex consisting of the unity of verbal, action, and other components. Besides, there is a long overdue social and cultural need for paying attention to folk medicine and anthropological knowledge, resulting from an increased demand for the services of alternative medicine doctors among people and, at the same time, expanded non-critical borrowing of parascientific explanatory schemes and models of the 
world in mass culture. Resorting to the folk tradition knowledge brings the issues of ethnopsychology of doctoring to the foreground, when it appears vital to appeal to the harmony of humans with the surrounding world, an idea central to Belarusian folk medicine.

Early childhood, as a period of particular importance, semantically multidimensional and full of symbolic procedures, has definitely attracted attention many times both in Eastern Slavonic folklore studies and in the European ethnography in general. In the Soviet science, Tatiana Tsyvjan was among the first to pay special attention to the semiotics of childhood, analyzing the status of the very child, as well as space and time in the rites of the first forty days after childbirth with the use of Balkan materials (Tsyvjan 1982). The 'transitional nature' of the life-cycle rituals becomes an important topic in Albert Bayburin's concept, whose works are fundamental in the development of a detailed and well-grounded semiotic approach to traditional culture. Through the prism of his views, it appears possible to suggest explanations of a disease as one of the clearly manifested samples of non-correspondence between the biological condition and the social status of an individual, which folk medicine rituals aim to eradicate (Bayburin 1993).

Another particularly important law of the archaic vision of the world is normativity - in Irina Sedakova's early childhood scenario study. Ideas about the norm and the limit are important for all cultural spheres; however, they are particularly well-manifested in traditional views of a child. Each individual has a certain lot, and even in details there is pre-determination and standardization (Sedakova 1999). The incantations of childhood are considered in Tatiana Agapkina's paper (Agapkina 2006).

Early childhood appears in traditional conscience as a certain period of transition, when the child is gradually freed from 'chaotic' signs, overcoming the other-worldly influences, developing his or her human appearance and finally affirming as a full-fledged member of society. Ties with 'that' world for the infant are not yet finally broken; there always remains a threat of backtransition. As Albert Bayburin states, childbirth leads to the appearance of non-correspondence between the very fact of a person's existence and absence of their human status. The goal and tasks of any ritual are to eliminate this noncorrespondence. The strategy of ritual acts of the first year of childhood lies in liberating the newborn from 'natural' characteristics and simultaneously providing them with cultural qualities and characteristics. The ritual development of the human being includes several basic elements: reaching the necessary form (shapes, sizes); obtaining the capacity to see, hear, move, and then 'the inside': the ability to speak, remember, and feel. Naming completes the process of the creating of a new semiotic object, ensuring its accession to the semiosphere. 
It is necessary to provide them with a lot. Simultaneously, there takes place separation of the infant from the 'alien', the natural, and his or her inclusion into the world of people (Bayburin 1993: 60-62). Ensuring calm sleep, ability to learn to walk and speak in time, regulate urination, and acquisition of the first communication skills are considered to be the necessary components of child socialization. Such is the scenario of ritual conduct for every fact of birth. But there occur, in particular, in early childhood, a number of deviations and drawbacks, of which diseases are the most important.

According to ethnography data, infant diseases in the past, up to the midtwentieth century, were a frequent phenomenon, in particular if we take into account quite a high percentage of child mortality. Moreover, a number of specific diseases of the first two months of life can be distinguished. The Belarusians of the Western Dvina basin region separated mesiachnik (month) (Wereńko 1896: 139) and mesiachyna - the period of particular child susceptibility to diseases (Nikiforovskiy 1897: 37). Child diseases are perceived as a manifestation stipulated by the very fact of birth, as well as a marker of the natural in the human body.

\section{CHILD CONVULSIONS AS A MARKER OF INFANCY}

Infantile paralyses, accompanied by epileptic seizures, both inborn and postpartum ones, were a rather wide-spread phenomenon in the nineteenth century, for example "U čylavieka chut́ adzin radzimiec da byvajet, čylaviek biez radzimca ni pumirait'" (Any human must have at least one of such seizures, no human will ever die without having such a seizure) (Dobrovolskiy 1914: 765). People even believed that each human is born with major or minor proneness to epilepsy, but in some people it is manifested by hysterical laughter, while in others - by crying, and yet others - in somniloquence; those who have had none of these will sooner or later be attacked by the evil disease (Nikiforovskiy 1897: 27); compare the same in Russian (Burtsev 1902: 68) and in contemporary records:

Dziecinaje je. Jano ŭ sredzinie buvaje. Eto chorošo, jek vukinie navierch. Dzieckoja chvoroba. Eto chorošo, jek vukinie navierch, i dzicio pokaže. Odno spić, snom prochodzić, druhoje śmiejecca, trecia može plakać. A čacviortoho i pienka moža z rocika pujci. U každaha, u každaha dzicionka, biez etaho nie buvaje. A jak nie vyjdzie, to budzie hodoŭ do siemi tak, orhanizm slabieńki, poka ŭ rost voźmiecca. ${ }^{1}$

The child disease is there. It may be inside. It is good if it gets manifested on the outside. Child disease. It is good if it shows itself, and when the 
child shows it. One infant sleeps, and in sleep it goes, another one laughs, yet another one will cry. Another one will have foam at the mouth. Each, absolutely each child has it. And if not, it will be going like this by the age of seven, the organism is poor, until they start growing.

The origin of the word radzimec is connected to the meaning 'inborn'. In the Pskov region, people differentiate малотник (malotnik) - "u ryabonka byvayet' tak, shto rebonak sausem vot na krayu smerti" (it may happen with the child that he or she is close to dying) (Mekhnetsov 2002: 334), in the adjacent Harodok raion of Belarus - малочай (malochay). The boundaries between the other world and the infant who has come from it are still highly transparent, not reinforced through complex symbolic actions, which become the core of family rites; therefore the child is more vulnerable to diseases.

Along with the recognition of the child's personality in the mother's womb (see Baranov 1999: 15-16), there should also be stressed understanding of its other-worldly nature by traditional conscience. There is a Macedonian belief, according to which a child in the womb is dangerous for the mother, she was tied with a belt to "better detect the enemy" (štopoveḱe grubi dušmano) (Zadrożyńska \& Wrocławski \& Vrazinowski 2002: 41-42). The child in the womb seemingly 'collects evil spirits'. Julian Talko-Hryncewicz characterizes them while describing child convulsions in the Ukrainian folk culture as the ones 'brought from the other world' (Talko-Hryncewicz 1893: 119). In general, such characteristics of the fetus stem from the other-worldly-chthonic interpretation of the woman's womb, understanding of the child as an envoy from the other world and a 'guest' (see a saying in the Belarusian family rite "Boh da nas čužaziemca pryslaŭ, jon z daliokich krajoŭ prybyvaŭ” (God has sent a foreigner to us from distant lands)). The idea of the inborn nature of the disease along with a clear realization of its demonic essence allows to assume the vision of radzimec as a kind of the other-worldly human atavism, as the other-worldly substance, which accompanies baby delivery.

A multi-stage, expanded delivery-baptizing complex basically aimed at liberating the child from the influence of the other world and at their gradual entering the society. Naturally, at a certain stage of baby delivery the mechanism of transition could fail, and a certain part of the other-worldly nature remained in the infant's body, causing convulsions and other epileptic seizures. In this respect, the following magic medical ritual is indicative: The mother sat on the sick child's face with a naked body, closing him or her with her skirt, and said three times: "Wherever you have come from, go there" (Novak 1998: 133). In fact, here it is the disease origin in the other-world space through the woman's maternal passages that is pointed to, and the demon of disease is removed in the same way in which it came to the human world. 
A number of magic actions aimed to treat the radzimec (child convulsions) are meant not to give the child back, but just as an attempt to spread 'that' world in 'this' one. Therefore, it was first recommended to consciously model the anti-world, intentionally overturn everything in the house, to make the house look just the opposite: "The child is put in the baby carriage with their legs to the top, an inturned shirt is put on them with the sleeves on the legs, in the daytime windows are covered or closed, and in the nighttime lighting is made more intensive" (Nikiforovskiy 1897: 38). Here also fits the prescription to cover the child with a black cloth, the Bulgarians even covered the sick child's face and hands with coal, and then forbade to bathe them for nine days and take them out of the house to have it 'blackened there' (Bogdanova 1985: 306); see also a record from Polesia, reading: "Končajecca dityna, ne mohla snuty, plače, jak hlucha nič" (The child is dying, cannot sleep, cries as a dead night). The witch doctor whispered something and advised not to point at them, not to call them by the name and to close the eyes with a black bandage. If you do it for nine days, they will live, otherwise they will die (Strakhov 2005: 175). In the latter case, particularly indicative is the prohibition to call the child by name, their symbolic deprivation of name is one of the brightest indicators of culture. The complexities of each stage of a small human's growing were accompanied by disease manifestations, and their successful combating meant the steps towards the child's entering the society.

\section{CHILDBIRTH AND SHARE RE-DISTRIBUTION}

All the newborns had to go through the main stages of socialization. And socialization proper, which started with the moment when the midwife took the child, cut the umbilical cord on the instruments of labor or on a book, covered with the parents' worn clothes, continued with the first bathing, putting on the first shirt, tying with a belt, ablactating, 'cutting of manacles' at the first step, etc. Through a series of ritual acts the child was included into the society and the world due to necessity, but this was not always smooth and flawless.

The re-distribution of the lot in society (family, village) caused by the childbirth received its ritual manifestation in the post-delivery visits paid to the woman by female neighbors, in the so-called 'old ladies' porridge' at the baptizing ceremony, etc. But in traditional conscience a human being is a component of a more expanded structure than just family-dynasty-village, and the newborn is included as an equal part into the interconnected and complementary society of people - non-people, which, besides humans, includes animals, primarily domestic animals, plants (see a symbolic exchange of health with trees), and 
a whole number of invisible estate residents (starting with home spirits up to evil demons). The appearance of a new unit, a small human being, who is thought of as a gift from beyond-human, sacral spheres, violates the relations set and regulated by a number of ritual prescriptions in this social and mythological structure.

Child's health in this context directly depended on the correct re-distribution of the lot (possessions) among other non-human estate residents. It is indicative that a child has the qualities of his or her neighbors - fur and unregulated cries, borrowed from animals and birds, extra activity at dawn, ability to see the future - from specific spirits, etc. Therefore, obtaining his or her lot of the overall reserve by the child and their ritual treatment is accompanied by regaining the natural characteristics, returning the things that are not theirs and are not necessary to the child to the right address: fur - to an animal, cries - to hens, insomnia - to dawn, etc. It may be said that treatment operations relating to little individuals typologically fit well into the symbolic procedure of re-distribution of the general (collective) lot, of which not only representatives of human society proper are recipients.

An important stage of the child's entering the surrounding space is the regulation of relations with animals (see below the complex relating to diseases of the type strands of fur) and natural and space world, which may be exemplified by a symbolic exchange with the forest spirits and heavenly phenomena (stars, dawn) in the 'texts' of nachnitsas (night owls). Another level is the establishment of parity relations with the demonic world - nachnitsa (night owl), Rus. polunochnitsa, Serbian babice, etc. Warning a child against their harmful effect is supplemented with steps taken to make those demons satisfied. And finally, of importance is the acquisition of the skills of communicating with people, teaching how to behave among people. Failures at this stage could lead to bad behavior.

\section{Relations 'child - natural and space world'}

Up until now, pregnant women have been cautioned against kicking domestic animals, caring too much for them, otherwise there will be hair on the child's back.

Eta jak chadzila maci biaremienna, svinnionka kavirala nahoj. A nikahda nie nada. Vot jej ničoha, a malomu zaŭradzila, ščacińnia vot takoja. Koliecca, vot i kryčyć hvaltam. Nikavo nielzia nahoj. Eta dzicia liečuć. Śvinniej vyhaniajuć sa svinarnika $i$ ŭ hajno, dzie jany liažać. I maloja heta zakapavajuć, na čas zakryvajuć u heta hajno. Jano i liažyć. I jano prachodžaje tady toja šarscinnia. ${ }^{2}$ 
When the mother was pregnant, she pushed a piglet with her leg. And you can't do this. She is okay, but that brought damages to the child, such fur. Spiky, so he is crying inside. You cannot kick anybody. And the child needs to be treated. Pigs are taken from the shed and the child is placed on the straw where they used to be for some time. And he stays there. And the fur will thus disappear.

The ideas about the disease characterized by the appearance of abnormal fur, hair on the body, stress the realization of a certain conditional measure of hair availability, and allow to reconstruct the mythology complex related to the universal idea of correspondence between the biological/social status and the degree of 'hairiness'. At the level of names of such diseases the Belarusians have several rows, united on the basis of manifestations of symptomatic nature: 1) 'sound', which stresses abnormal sound behavior - kryksuny, kryktuny, kraktuny, kraktuchi; kryklivicha, kryklivicy, plaksuny (crybabies); 2) 'visual', which fixes beliefs of appearance of disease-bearing hair on the child's body-valasnik, valasnica, valasianica, svinskaja šersć, šarscinnia, šarscinka, svinnaja šersć, kacinaja kaliučka, dzikija valoski (fur, hair). Ukrainians denote such a disease as volas (Talko-Hryncewicz 1893: 121), the Russians of Siberia - shchetina (bristle) (Vinogradov 1915: 375). The third row can be represented as a 'zoomorphic' one: “Sabačča starasć. Eta takoja šarscinnia vyrastaić. Luhu zavaravajuć, popielu i kupajuć. Takija valaski na spinie ŭ rabionka, jany koliucca"3 (Dog's old age. Such fur grows. Ashes are boiled and the baby is bathed in it. Such hair on the child's back. Spiky); Russian sobachia starost 'insomnia and no appetite of the child resulting from the violation of the ban when a mother steps over a cat' (Olonetsk region; Kulikovskiy 1898: 72); sobachinka (Vologodskaya region; Berezovich 2007: 513). Similar names can be found in other nations - Bulgarian nèceu 'infant disease when they get weaker, and grey fur grows on the body', nѐсùua, пѐснѝuа - the same (BER 1996: 186-187); Serbian nешuцы (Tolstoy 2003: 372); Polish psiarka 'red spots on the child's body' (Karłowicz \& Kryński \& Niedźwiedzki 1912: 413). Rachitis in the Volgograd region was denoted as koshach'i sukhoty (feline tuberculosis) (Berezovich 2007: 513), while Bulgarians pointed to the disease of мачетини (machetini), which appeared as a result of violation of the ban to call a child a cat - machka (Sedakova 2007: 31).

The 'bird' series of child diseases is made up by the names like крылішчь (krylishchy), крылльска (krylyska), appearing when a hen goes in-between the pregnant woman's legs. Only children at the early infancy stage suffer from those diseases, in some records such semiotically important intervals as a sixmonth age or a year are stressed: "Jak maleńki, do šesti miesiace, buǔajut krylyska" (When an infant, up to six months, there may be krylyska) ${ }^{4}$. Significant seems to be an emphasis on the fact that such disease may disappear on 
its own, when the period of its appearance 'allowed by tradition' expires, as well as an emphasis on the frequency of such behavior of infants, which once again underlines the organic nature of such infant diseases in the first year of life scenario.

The appearance of pimples, fur, and hair on the child's body is perceived as a result of beyond-norm connection of a pregnant woman with pets and birds, the semantics of which contains a chthonic element. This marker is transferred already in the mother's womb, which is symbolically equal to the other world. Excessive, non-regulated contact of a pregnant woman with the creatures opens up access of infernal forces to the child, activates the disease-causing effect of the other-world things on the small human being. Such supernatural hairiness makes the chthonic component in the child's body more intensive and constitutes a marker of the child's nature, not yet overcome by belonging to the other world. In indicative riddles, a child is represented as an animal: "Što za zviaročak: pa chacie chodzie, nichto jamu nie škodzie" (What an animal is it that goes about the house and nobody ousts it) (Zahadki 1972: 344). Worthy of attention is the fact that almost all popular Bulgarian names of unbaptized children coincide with designations of small pets (Walczak-Mikołajczakowa 2001: 32). At the same time, comparison of a child to an animal appears logical since "figuratively, transformation of the child's appearances can be represented, somewhat conditionally, as his or her passing through several conditions: starting with the 'inanimate' substances of nature (rock, bone, root, ovary) and creatures belonging to 'animal nature' of the chthonic circle (amphibians, rodents) to a human being" (Baranov 1999: 26).

Through the prism of disease perception as intervention of a demonic essence into the human body or activation of the 'inborn' chthonic component, treatment was based on the dominant idea of a removal of the 'alien', achievement of the generally accepted norm of 'humanity', one of the manifestations of which is absence of hair (fur) in non-characteristic places. Removal first presupposed a kind of materialization of symptoms, concentration of hair and fur, which were of a concern for the child, in a number of attributes, which include ashes, bread, flour, breast milk. Some records suggest deleting it with saliva or salt. Magic elements of the treatment of 'fighting fire with fire' are manifested in smoothing out with fur - '(smoothed out) with fleece... from a coat's; 'Rolls were made out of a dog's fur and smoothed out on the child's body'6.

Rolled hair was either destroyed or removed into the sphere of beyond-human - '(bread) was thrown behind the stove, for mice to eat it'7; 'thrown to the places where there is nobody'8. The most frequent indication is that such bread was given to the dog to eat: 'Soft bread is taken from kraktunou (crybabies), and rolled on the back. And then it should be placed on the window to stay there, 
and then it is given to the dog'9. In some rare cases the sick child was fumed with the rolled fur (Wereńko 1896: 206). The procedure was conducted in the chronotope typical for folk medicine practices and mainly during/after bathing. The magic inventory was prepared in compliance with certain rules - "three days after bathing to put four heaps of ashes sifted through the top-down sieve on the spade located on the threshold in turns crosswise. To sweep the ashes in the same order into the water and bathe the child" (ibid.). The ashes could be sifted, holding hands behind the back, ${ }^{10}$ and bread was taken from the place where the sign of a cross was put on the dough (Lapatsin 2004: 248). In the beliefs, ashes could by themselves 'absorb' such hair. ${ }^{11}$ Bulgarians bathed the pesčavo dete (sick child) in water with such ashes, and then poured the water onto the cat (Bogdanova 1985: 305).

Baba klala dzicia nicma, nakryvala jaho nočvami. Z-pad kryla čornaje kurycy vyryvala dzieviać pieryn, viazala ich pa try ŭ try pučki, siekla na nočvach nažom. Maci vychodzila za dzviery i pytala: "Što siačeš?” "Krylišča." - "Siačy, kab nie bylo." I tak try razy. ${ }^{12}$

The woman put the child on the back and covered the child with a trough. She took nine feathers from under the black hen's wing, bound them in threes into three bundles and cut with a knife on the trough. Mother went out of the door and asked: 'What are you cutting?' - 'Krylishcha.' - 'Cut for it to disappear.' And three times like that.

In case the ritual was connected with cats and dogs, they were given the bread with rolled hair, while in the context with pigs other mechanisms were accentuated. Bread was not given, the child him- or herself was taken to the swine shed (that's what Lusatian Serbs did for the child to sleep well (Schneeweis 1935: 62), rolled from one place to another there ${ }^{13}$ and "nasili, jak krylišča, u toja stojla, dzie svinni stajać. Kladzie na paroh. Paliažyć, paliažyć i ŭsio” (carried, in case of krylishcha, to the stall where the pig stood. Put on the threshold. (S)he lies there a bit, and that's it) ${ }^{14}$. More frequently recorded as pieces of advice are "to take the child, put him or her under the threshold, cover with a trough, make pigs move across it" (Federowski 1897: 391). The unification of pigs, cats, dogs and hens within one text can be traced in the case of treatment of a 'pig miracle' by Russians in Siberia (Fedorova 2001: 61).

It is indicative that even the spirits bringing harm to children acquire the shape of domestic animals (Biegeleisen 1927: 259, 357). Particularly popular in the ritual treatment of infant diseases were domestic animals. It is essential to find a semantic correlation between the image of a child and small domestic animals and pets (cat, dog, and pig) on the basis of their stressed marginal status between the wild and the mastered (domestic), which is based on their 
separation from the wild and the alien, inability to regulate their physical needs, absence of speaking ability, etc. In any case, fur obtained from domestic animals was given back to them.

When researching the semiotics of crying, including child crying, I. Sedakova appeals to the important law of archaic vision of the world - normativity. Ideas about the norm and the limit are important in all the fields of culture, but they are particularly well-manifested in the traditional views of the child. Each person has a certain destiny, and even details already contain pre-determination and normativity. Each child has a limit of crying (loudness and duration), which, if exceeded, does not fit within the limits of the regulated world. Excessive crying is perceived as inhuman and is connected in the traditional conscience with the limit of nature and culture or goes into the field of demonology (Sedakova 1999: 113).

The same can be said about the child's hair, since its appearance in excessive, or, vice versa, insufficient amount stresses the realization of a certain conditional limit of hair, deviation from which causes painful symptoms and is in itself qualified as not just a disease, but the intervention of the alien and demonic. The ban to cut hair and nails until the child is one year of age is among the most wide-spread bans, and the most frequent motivation is the danger to cause delays in the speaking ability manifestation. Tradition recognized the 'alien nature' of those parts of the body and therefore any striving to adjust growth was of a ritual nature. Human transition from one age group to the other one was normally accompanied by manipulations with hair. The first haircut, marked by a ritual, provokes the ability to speak, and finally pre-determines the status of the individual. The adjustment of 'hair degree' and removal of beyond-norm part of it also constituted a necessary step towards growing up of a little human.

Uncontrolled urination is a norm for an infant, the same as incapacity to walk or talk. Absence of control over this physiological function of the organism in a certain sense makes a child like an animal, pointing to the 'natural', 'elemental' in humans. But the first skills of 'potty-training' a child approximately coincide with the first progress in mastering speech, with improvement of motor functions, etc. Therefore, ritual regulation of that process can be considered as one more component of child socialization, his or her consistent affirmation in human status (Valodzina 2004). 


\section{Relation 'child - the world of demons'}

Dependence of a child on different infernal forces, subordination to them, and a respective need to communicate with them found their manifestation in a complex of ideas about specific children's spirits and demons, which, due to their demonic nature, could cause insomnia and disease-caused crying of children. In Belarus those demons are called начніца (nachnitsa, night owl) (see other versions, such as начнікі (nachniki), крыксы (kryksy), плаксы (plaksy), крактунь (kraktuny), etc.). In P.V. Shein's collection, "nachnitsas are presented as women in dark clothing (more rarely - in white dresses), they come in a barely audible way, sit on the bed and touch humans with their hands. As a result of that, he or she becomes insomniac and can even die" (Shein 1893: 537-538).

Permanent crying of the child in the nighttime proved that nachnitsas resided in the house and were bringing harm to the child. One of the locusesshelters of nachnitsas was the stove, since it was here that sacrifices were offered to them:

You need to take a slice of bread with salt, cover it with a white wipe, tie with a red thread, and then take the child and pat his or her head with this knot and put it on the stove. And then bow three times to the stove without making the sign of the cross and say: 'I am giving you, kriksas, bread and salt, white shirt, red belt, give good health and sleep to my child'. (Romanov 1891: 31)

It appears that kriksy, nachnitsas cannot only take sleep away, but also 'give' it; see also a saying from Polesia: "Načnicy, načnicy, na dziciatka son naviedzicie..." (Nachnitsas, nachnitsas, give sleep to the child...) (Polissya 2003: 71). It was under the stove that other home spirits resided, and primarily that was the bogey that could also perform some patronage functions. Here is an indicative folklore fact from the Hrodna region:

A baba Handzia havaryla, što jeść try vida damavych. Damavy, katory niačystaja sila; damavy, katory spryjaje; $i$ damavy, katory dzieci kalyša. Maje dzieci ŭsio nie spali, tak ja vyjdu i kažu: Baba hadavanka, dzie toj damavy, što dzieci kalyša? ${ }^{15}$

And old lady Handzia said that there are three types of bogeys. A bogey that is an evil one, a bogey helping you, and a bogey singing lullabies to children. My children did not sleep well, so I went out and said: Where is the bogey singing lullabies to children?

Possibly, nachnitsas/kryksas were one of the forms of embodiment of domestic spirits, which, in turn, are genetically linked to the souls of the ancestors living 
in that house. The folk tradition regulated relations between living and similar 'residents' of the house with the frame of the 'peaceful co-existence'. In case the 'agreement' was violated and 'the other' party interfered in human affairs, it became necessary to neutralize it and to re-set the boundaries. Success in treatment could be ensured through a combination of magic actions, when the neutralization of excessive disease-causing activity of spirits-nachnitsas was combined with the re-distribution of space and possessions, as well as the removal of supranormative demonic remains out of the house, but - and that is important! - to the locuses of their shelters within the estate. Such simultaneously 'own' and 'alien', specific demonic locus is a heap for litter as a magnetic concentration of the chthonic nature and direct way to the other world. "A child is placed on the bedsheet spread on the floor in the middle of the house, then litter from everywhere is swept to him/her, and then the bedsheet with the child is taken out of the house to the litter heap and thrown away" (Vasilevich 1999: 181). A locus that belongs to such spirits as well (old and young) is also the corner of the house:

Biareš dzicia nosiš jaho, treba havaryć: "Va imia Ajca i Syna i prašu Maniu i Hospad Boh pamažy.” A tady: "Dobry viečar!” I niasieš jaho na kut spierva. "Dobry viečar, staryja i malyja, dajcia Koliu son.” Tady niasieš u druhi kutok, tady u toj, tady ŭ toj (nakryž pakazvaje) "Dobry viečar, staryja i malyja, my nie huliać $k$ vam pryšli, kryksy i načnicy pryniasli”. Pierachrysciš i niasieš u druhi kutok. "Dobry viečar, staryja i malyja, my nie huliać $k$ vam pryšli, kryksy i načnicy pryniaśli. Vam plakać, nie spać, a majmu Koĺku spać, huliać, tancavać, apiecit nahaniać."16

You take the child in your arms and carry him or her, saying 'In the name of the Father, and the Son, and Manya [name of the whispering lady] and let God help'. And then: 'Good evening,' - and take him or her first to the red corner. 'Good evening, old and young, give sleep to Kolya.' Then you take him to that corner (the opposite one), then to the other two (to make the sign of the cross). 'Good evening, old and young, we have not come here to have a walk, kryksas and nachnitsas - that's whom we have brought. For you - crying and no sleep, and for my Kolya - sleep, walk, dance, and have a good appetite.'

The analysis of such rituals enables us to perceive nachnitsas as a kind of domestic spirits, the system of functions of which included tracing and regulation of upbringing operations. Only a newborn child, right after coming 'from there' and due to his semi-other-worldly nature, penetrated into the field of their possessions and guardianship possibilities. The function of taking care of the child and ensuring his healthy sleep is also ascribed to 'kukolkas' (dolls) 
(a real materialization of domestic spirits), which were placed on the window: "If a nachnitsa gets to the child, you need to make dolls of dirty wipes, place two or three of them on each window and say: 'Look, dolls, my child needs to sleep well!' - otherwise nachnitsas will come" (Federowski 1897: 270). An emphasized female look of nachnitsas was manifested in a number of functions they seemed to have - and that is some connection with the sphere of reproduction and weavery.

Divčyny iz lučyny robliać veratino, pad holovu kladuć. Nočnycu uhavarvajuć: "Nočnyca, šerańka! Ne ihraj moim ditynam, ihraj veratinom da lapačkaju."17

A spindle is made for a girl out of a rod and placed under her head. Nachnitsa is told: 'Nachnitsa, the grey one, don't play with my child, play with the spindle and the wipe.'

Weaving and child care fit well into the traditional structure of the female variant of a domestic spirit, for whom such occupations were immanent. On the other hand, some contexts point to a possible stipulation of nachnitsas by the very fact of child birth, to their 'inborn' belonging to each person. If we address the rituals of offering a spindle to a girl and a bow to a boy, of interest is the dependence of the gift on the child's gender, in correspondence with which the character for the ritual was attributed by gender. Thus, the specificity of the image of the nachnitsa was "her lack of independence and even mirror reflection, since her characteristics are the projection of the child whom she was to influence" (Fadeeva 2000: 38). In other words, night disease-causing spirits still appear together with the child, accompany his or her birth and the first years of life. Indicative is the fact that the child is called by the names of spirits Ukrainian krieksoj, maroj, ničkoju, as if he or she has absorbed the features of those mythological creatures (Bogdan 1987: 194). Incantations partially identify nachnitsas with children, and such identification was further developed in the motives of 'nachnitsa's insomnia' and 'making nachnitsa fall asleep' (Agapkina 2006: 26). The ritual practice in which "ot nočnyc prača ŭpovyvaly, vykidaly za oknu. Vykinut tuju nočnyciu praz okno: kab uže taja nočnycia na toj prač uzliezla"18 (the gingerbread was swaddled against nachnitsas and thrown out of the window. One should have thrown the nachnitsa out of the window for her to already get on the gingerbread) and at the same time this gingerbread that was the embodiment of nachnitsas persistently assigned the image of the child (Szukiewicz 1910: 116). 


\section{Relations 'child - society'}

Before the child is fully affirmed in the society, it is necessary to set contacts inside the purely children's community. The ideas relating to this stage are reflected in a set of beliefs about a specifically Polesian child disease - znos (знос). Знос (znоs), зносінь (znоsiny) is an accidental meeting of two mothers with children on the way (the first meeting of children is meant). Such meeting is highly undesirable, since, according to a popular belief, one of the children who is above the other will take away his or her force, and the latter will stop growing, will start crying and being ill, and may even die. To become a winner in such meetings, children were taken up, tossed up. "Ona vyšej podniala. Koli jeje dzicia moje pobiedzilo, to jeje budzie zdorovoje, a moje budzie plakać"19 (She put him higher, if her child wins, he/she will be healthy, while my child will cry). The action part of the ritual is reinforced with the verbal one: the mother pronounces aloud or in her mind the following phrase-incantation: "Maja vaŭčenia, a tvaja - kozlienia. Maje tvaje zjesć" (Mine is a little wolf, while yours is a little goat. Mine will eat yours) (Salavey 2006: 92).

While researching child diseases in the social context, it is important to know that the health and destiny of little children seemed to be joint ones, they were not shared by several children in equal parts, and the child was to obtain his or her lot, as it seemed, at the expense of another child. The incantation formulas primarily show striving for providing children with equal, same parts: "Odyn svit, odyn mir, / Odnakovy batky, odnakovy matky, / Nechaj budut odnakovy dytky" (One light, one world, same fathers, same mothers, let children be the same) (Polissya 2003: 87), for ensuring 'just' division between them: "U jaho holovka, u toho holovka, u jaho pliečyca, u toho pliečyca, u jaho sustaǔčyki, u toho sustaǔčyki" (This one's head, that one's head, this one's shoulders, that one's shoulders, this one's joints, that one's joints $)^{20}$. Such division organically includes everything around, when the disease was sent to the place where it attacked the person (it was recommended to take some sand at the place where the meeting had taken place, bathe the child in the water with this sand and pour the water out onto the same place) (Polissya 2003: 84), and children's health was seen in 'space' parallels: "Soniejka i miesiačyk, i vas, dzietki, dvoje, - žyvicie aboje" (The sun and the moon, and there are two of you, children, - live both) ${ }^{21}$.

Getting rid of whims due to their perception as a disease presupposed not upbringing activities and not moralizing, but radical medical procedures. The etiology of the disease, which was often brought down to appearance of a harmful substance in the body, presupposed its removal and expulsion. Hence the predicate expel in the terminologically stable designations of folk medicine manipulations: “...usio kariožycca, plačyć, jetyja kaprizy nada čym-niebudź 
vyhaniać" (...tumbles, cries, these whims need to be expelled) (Bialkevich 1970: 221); "Vyhaniali karady dzierkačom" (Whims were expelled with an old broom);22 "Biaruć dubiec tonki, adžaruć, adžaruć, tyja naravy vyhaniajuć" (They take a thin oak branch, beat him, beat, and expel the whims) ${ }^{23}$ Folk therapeutical rituals of getting rid of whims in the most general form can be represented as follows: the sick child was placed into the locus with meditative semantics and beaten with specially prepared rods.

A kapryzy byvajuć, što pavalicca? - Jak pariucca ŭ bani vienik, nada toj vienik razabrać i najci takuju vietačku, katora tri, štob tri sučki bylo i jetym nada ściebanuć $i$ raz, i druhi, raziki tri. Boĺna nie, a ściebaješ. ${ }^{24}$ And whims may be that [the child] falls down? - While in a bath, one needs to disassemble the broom and find the rod having three knots, and beat the child three times. Not to cause pain, just mildly.

In the absolute majority of records, the ritual action takes place at the house threshold. The sick child is put at the threshold, in some cases - with his or her head to the exit, to the anteroom, which intensifies the vector of disease expulsion. Depending on the further ritual step, either the attribute of the rite is thrown out of the house or the very child is taken out of the house; see also "Eta nazyvajecca upiry. Nu dyk havorać, budta by ad paroha načynajuć etaha dzicionka da abrazoŭ vo tak vo halavoj kuliać. Eta ŭpiry"25 (These are upiry. They say that they start making the child tumble up to the red corner from the threshold. That results from whims).

\section{CONCLUSIONS}

Early childhood has shown the following segments: relations 'child - natural and space world' are characterized by their set of diseases (kraktuny, ščacinka, šarscinka, etc.) and are aimed at the ritual regulation of relations with the ani$\mathrm{mal}$ as well as the natural and space world. This is illustrated by the symbolic exchange with domestic animals in the text of načnic/kryksaŭ. The adjustment of 'hairiness' and removal of its abnormal part constituted the necessary step to be made towards maturity of the little human. The next level is the establishment of parity relations 'child - the world of demons'. Protection of the child from the harmful influence of demons is supplemented with measures taken to cajole disease-causing spirits like načnic, kryksaŭ. But some contexts point to the possible pre-determined nature of nachnitsas caused by the very fact of childbirth. Incantations and rituals demonstrate symbolic inclusion of nachnitsas into a single complex which started in the period of the woman's 
pregnancy and lasted up to the final affirmation of the child in this world. And, finally, topical is the acquisition of the skills of communicating, learning how to behave among people. Failure in relations 'child - society' could result in bad behavior, as well as be manifested in a set of beliefs about a specific Polesian child disease - znos.

Almost each of the child's physiological abilities in folk beliefs acquires a number of characteristics, which points to their changeable status. Voice, availability of teeth, hair, appetite, ability to walk, talk, and control urination are inherent in each child (human), but any deviations from the average manifestation of these functions are considered to be disease-caused and are accounted for by the reasons of sign character: charm, demons' impact, violation of rules of conduct and bans, etc. In its turn, the first manifestation of almost each of the characteristics seems to be semiotically significant: appearance of the first tooth, the first step (see the holiday Prestypulka in Macedonia 'the day of the first step' (Walczak-Mikołajczakowa 2001: 39). Alongside medical manipulations, it is possible to consider both first bathing and baptizing, which are full of ritual and symbolic sense. The first years of life can be relatively perceived as a chain of transformations, the semantics of which is manifested in a number of indicators: attributes - hairy / smooth, naked; toothless / with teeth; dirty (with unregulated excretory system) / clean; predicates - to sit / to walk; to keep silent / to speak; to sleep / to stay awake, etc. As we can see, the left parts of the pairs form a paradigm of description of the alien, non-human / demonic, sickly, negative. "The description of a child, his or her internal nature and external appearances in the child/adult pair, is performed through negative, distorted signs" (Baranov 1999: 26).

Child diseases in the traditional sense are rejoinders of the other world, manifestation of not yet clear chaotic natural signs and, along with that, a phenomenon pre-determined by the very fact of birth. Healing strategies consist, therefore, not in the straightforward removal or destruction of disease-causing demons (cf. načnicy/kryksy), but in the establishment of parity relations with them. The ideas about diseases of the kraktunoŭ (valasianica, šarscinka, krylyska) type stress the realization of a certain conditional measure of hair availability and enable to reconstruct the mythological complex connected to the universal idea of correspondence between the biological/social status and the degree of 'hairiness'. The idea of correct re-distribution of the lot at all the levels of the universe becomes central to the disease-free maturity of the child. Making sleep calm, timely appearance of the ability to walk and speak, to regulate urination, mastering the rules of cultural communication, and equalizing of the appearances are considered to be the necessary components of any child's socialization. 
The idea of the new birth of the child is organically combined with the need for his or her 'correct' inclusion in this world, provision of the child with his or her own lot. Overcoming the marginal condition of the child points to some national implications, while prevention and therapeutical procedures confirm the idea of the need for harmonious co-existence of humans and the surrounding world with all its infinity.

\section{ACKNOWLEDGEMENTS}

The article was written as part of a project financed by the Foreign Ministry of Estonia through the Developmental Cooperation Programme (66-2015-A).

\section{NOTES}

1 Recorded in 2009 by T. Valodzina in the village of Perarou Mlynok, Zhytkavichy raion, Homel region, from Eva Adamauna Baran, born in 1946, and Nadzeja Adamauna Shved, born in 1927. In case no collector is further indicated, the records are those collected by the author.

2 Recorded in 2014 in the village of Lyubushany, Berazino raion, Minsk region, from Zinayida Mikhaylauna Karen, born in 1930.

3 Recorded in 2005 in the village of Valyntsy, Verkhniadzvinsk raion, Vitsebsk region, from Adelaida Filipauna Sheverduk, born in 1930.

4 Polesia Archive of the Institute of Slavonic Studies of the Russian Academy of Sciences; recorded in 1985 by V. Sannikava in the village of Lapatsin, Pinsk raion, Brest region.

5 Recorded in 2004 in the village of Ladasna, Lepel raion, Vitsebsk region, from Yefrasiniya Dzianisauna Kavalenka, born in 1939.

6 Recorded in 2007 in the village of Redziherava, Luninets raion, Brest region, from Uljana Piatrouna Parfianovich, born in 1928.

7 Recorded in 2006 in the village of Kukhoni, Ushachy raion, Vitsebsk region, from Varvara Laurentsjeuna Lytvyn, born in 1927.

8 Recorded in 2006 in the village of Shylintsy, Dokshytsy raion, Vitsebsk region, from Yauheniya Hryhorjeuna Sobal, born in 1925.

9 Recorded in 2003 in the village of Sialets, Chashniki raion, Vitsebsk region, from Matrona Kirylauna Kapustsina, born in 1909.

${ }^{10}$ Recorded in 2003 in the village of Sialets, Chashniki raion, Vitsebsk region, from Valiantsina Paulauna Piasetskaya, born in 1931. 
${ }^{11}$ Recorded in 1998 in the village of Yahadki, Ushachy raion, Vitsebsk region, from N.M. Bulaeva, born in 1913.

${ }^{12}$ Folklore Archive of the Scientific and Educational Laboratory of Belarusian Folklore of the BSU; recorded in 1998 by H. Lapkouskaya in the village of Pastarynje, Baranavichy raion, Brest region, from Lapkouskaya Lidziya Piatrouna, born in 1949.

${ }^{13}$ Folklore Archive of the MSPU (FA): recorded by L. Dulinets in the village of Mosar, Hlybokaye raion, Vitsebsk region, from Hunefa Vitoldauna Panfilko, born in 1919.

${ }^{14}$ Recorded in 2005 in the village of Alkhouka, Liakhavichy raion, Brest region, from Hanna Mikalayeuna Smarchok, born in 1930.

${ }^{15}$ Recorded in 1999 by A. Bohaneva in the village of Koniukhi, Vaukavysk raion, Hrodna region, from N. Harokhava, born in 1949.

${ }^{16}$ Recorded in 2013 in the village of Slabodka Sushanskaya, Klichau raion, Mahiliou region, from Maryia Yafimauna Lapunova, born in1928.

${ }^{17}$ FA: recorded by $\mathrm{H}$. Shgurko in the village of Sporava, Biaroza raion, Brest region, from Alena Datsevich.

${ }^{18}$ Belarusian Folklore-Ethnolinguistic Atlas; recorded by M.P. Antropau in the village of Belsk, Kobryn raion, Brest region.

${ }^{19}$ Recorded in 2007 in the village of Vulka 2, Luninets raion, Brest region, from Tatsiana Yafimauna Viachorka, born in 1935.

${ }^{20}$ FA: Recorded in 2003 by M. Razhalouski in the village of Starozhka, Zhytkavychi raion, Homel region, from Hanna Fiodarauna Yadvila, born in 1923.

${ }^{21}$ Recorded by V. Krasouskaya in the urban settlement of Aktsiabrski, Homel region, from Pelaheya Lukjanauna Sboryna, born in 1925.

${ }^{22}$ PA: Recorded in 1982 by A. Lebedzeva in the village of Dubrauka, Dobrush raion, Homel region, from Yeudakiya Ivanauna Danilchanka, born in 1912.

${ }^{23}$ Recorded in 2002 in the village of Vialiki Pousvizh, Lepel raion, Vitsebsk region, from Mariya Isaakauna Ivanava, born in 1933.

${ }^{24}$ Recorded in 2011 by T. Valodzina and U. Lobach in the town of Haradok, Vitsebsk region, from Yauheniya Fiodarauna Dzemianenka, born in 1936.

${ }^{25}$ Recorded in 2009 in the village of Stsiapy, Zhlobin raion, Homel region, from Katsiaryna Vasiljeuna Zhurauliova, born in 1934. 


\section{REFERENCES}

Agapkina, Tatiana 2006. Syuzhetika vostochnoslavyanskikh zagovorov v sopostavitel'nom aspekte. [The Plots of Eastern Slavonic Charms in the Comparative Aspect.] In: S.M. Tolstaya (ed.) Slavyanskiy i balkanskiy fol'klor: Semantika i pragmatika teksta. [Slavonic and Balcan Folklore: Text Semantics and Pragmatics.] Vol. 10. Moscow: Indrik, pp. 10-123. Available at http://inslav.ru/images/stories/pdf/SBF2006.pdf, last accessed on 13 April 2018.

Baranov, Dmitriy 1999. Obraz rebenka v predstavleniiakh russkikh o zachatii i rozhdenii. [The Image of Child in Russian Perceptions of Conceiving and Birth.] Extended summary of $\mathrm{PhD}$ thesis. Saint Petersburg State University. Available at http:// www.academia.edu/6232107, last accessed on 18 April 2018.

Bayburin, Albert 1993. Ritual v traditsionnoy kul'ture: Strukturno-semanticheskiy analiz vostochnoslavyanskikh obryadov. [Ritual in Traditional Culture: Structural and Semantic Analysis of Eastern Slavonic Rites.] St. Petersburg: Nauka.

BER 1996 = Georgiev, V. \& Glbov, I. \& Zaimov, Y. \& Ilchev, S. (comps.) Bŭlgarski etimologichen rechnik. [Bulgarian Etymological Dictionary.] Vol. 5. Sofia: Bulgarian Academy of Science.

Berezovich, Elena 2007. Yazyk i traditsionnaya kul'tura: Étnolingvisticheskie issledovaniya. [Language and Traditional Culture: Ethnolinguistic Studies.] Moscow: Indrik.

Bialkevich, Ivan 1970. Krajovy sloŭnik uschodniaj Mahilioǔščyny. [Regional Dictionary of Eastern Mogilev Region.] Minsk: Navuka i Tekhnika.

Biegeleisen, Henryk 1927. Matka i dziecko w obrzędach, wierzeniach i zwyczajach ludu polskiego. [Mother and Child in the Rites, Beliefs and Customs of the Polish People.] Lwów: Ateneum.

Bogdan, Svetlana 1987. Svít polís'koî ditini: língvístichní rariteti. [The World of Polessye Child: Linguistic Rarities.] Políssya: Etníkos, traditsî́; kul'tura. [Polessye: Ethnikos, Traditions, Culture.] Lutsk: Vezha, pp. 193-199.

Bogdanova, A. 1985. Narodna meditsina. [Folk Medicine.] In: R. Todorov (ed.) Kapantsi: Bit $i$ kultura na staroto bŭlgarsko naselenie $v$ severoiztochna Bŭlgariya. Etnografski i ezikovi prouchvanie. [Kapantsi: The Daily Life and Culture of Old Bulgarian Population in North-Eastern Bulgaria. Ethnografic and Linguistic Studies.] Sofia: Publishing House of the Bulgarian Academy of Sciences, pp. 279310 .

Burtsev, Aleksandr 1902. Obzor russkogo narodnogo byta Severnogo kraya. [The Review of Russian Folk Daily Life of the Northern Land.] Vol. 2. St. Petersburg: Typ. I. Efron.

Dobrovolskiy, Vladimir 1914. Smolienskij oblastnoj slovaŕ. [Smolensk Regional Dictionary.] Smolensk: Tip. P.A. Silina.

Fadeeva, Liudmila 2000. Simvolika strastnykh ikon Bogoroditsy v zagovorakh. [The Symbolic of the Passion Virgin Icons in Charms.] Traditsionnaya Kultura [Scientific Almanac], No. 2, pp. 35-42. 
Federowski, Michał 1897. Lud Białoruski na Rusi Litewskiej. Materiaty do etnografii stowiańskiej zgromadzone w latach 1877-1905. T. 1. [Belarussian People in Lithuanian Rus. Materials for Slavic Ethnography Collected in 1877-1905.] Vol. 1. Kraków: Wydawn. Komisji Antropologicznej Akademii Umiejętności w Krakowie.

Fedorova, Valentina 2001. Chelovek $i$ slovo v zagovore. Yuzhnoye Zaural'ye: Konets XX veka. [Humans and Word in Charms. South Zauralye: Late 20th Century.] Kurgan: Publishing House of Kurgan State University.

Karłowicz, Jan \& Kryński, Adam \& Niedźwiedzki, Władysław 1912. Słownik języka polskiego. [Polish Dictionary.] T. 5. Warszawa: Kasa im. Mianowskiego.

Kulikovskiy, German 1898. Slovar' oblastnogo olonetskogo narechiya v yego bytovom i etnograficheskom primenenii. [The Dictionary of Regional Olonetsk Dialect in Its Daily Life and Ethnographic Applying.] St. Petersburg: Edition of the Department of the Russian Language and Literature of the Imperial Academy of Sciences.

Lapatsin, Genadz 2004. Z vopytu vyvučennia tradycyjnaj kultury Vietkaǔščyny: Vioska Bartalamiejeŭka. [From the Experience of Studying Traditional Culture of Vetkovshchyna: The Village of Bartalameyeuka.] In: H. Niačajeva (ed.) Navukovyja zapiski Vietkaŭskaha muzieja narodnaj tvorčasci: Zborn. art. [Scientific Notes of the Vetka Museum of Folk Creativity: Collection of Articles.] Homieĺ: Vietkaŭski muziej nar. tvorčasci, pp. 231-254.

Mekhnetsov, A. M. (ed.) 2002. Narodnaya traditsionnaya kul'tura Pskovskoy oblasti: Obzor ekspeditsionnykh materialov iz nauchnykh fondov Fol'klorno-etnograficheskogo tsentra. [Folk Traditional Culture of Pskov Region: Review of Expedition Materials from Scientific Funds of the Centre of Folklore and Ethnography.] In 2 vols. Pskov: Pskovskii gosudarstvennyi oblastnoi Tsentr narodnogo tvorchestva.

Nikiforovskiy, Nikolay 1897. Prostonarodnyye primety i pover'ya, suyevernyye obryady i obychai, legendarnyye skazaniya olitsakh i mestakh. [Folk Omens and Beliefs, Superstitious Rites and Customs, Legends about People and Places.] Vitsebsk: Gubernskaja tipo-litografija.

Novak, V. S. (ed.) 1998. Abradavy faĺklor Homieĺskaha Paliessia. [Ritual Folklore of Gomel Polessye.] Homieĺ: Homiel. centr navuk.-techn. i dzielavoj infarmacyi.

Polissya 2003 = Polesskiye zagovory (z zapisyakh 1970 - 1990 gg.). [Polessye Charms (in the Records of the 1970s-1990s).] Comp. and preparation of text commentaries by T.A. Agapkina \& E.E. Levkiyevskaya \& A.L. Toporkov. Moscow: Indrik.

Romanov, Evdokim 1891. Belorusskiy sbornik. Vyp. 5: Zagovory, apokrify i dukhovnyye stikhi. [The Belarusian Collection. Issue 5: Charms, Apocrypha and Spiritual Poems.] Vitsebsk: Tipo-litografiia G. A. Malkina.

Salavey, Liya 2006. Znosiny, znos. In: S. Sanko (ed.) Belaruskaya mífalogíya: Entsyklapedychny sloŭník. [Belarusian Mythology: Encyclopaedic Dictionary.] Minsk: Belarus, pp. 192-193.

Schneeweis, Edmund 1935. Grundriss des Volksglaubens und Volksbrauchs der Serbokroaten. Celje: Družba sv. Mohorja.

Sedakova, Irina 1999. Krik v pover'iakh i obriadakh, sviazannykh s rozhdeniem i razvitiem rebenka. [Cries in the Beliefs and Rites Connected with Childbirth 
and Child Development.] In: S.M. Tolstaya (ed.) Mir zvuchashchii i molchashchii: Semiotika zvuka i rechi v traditsionnoi kul'ture slavian. [The Sounding and Silent World: The Semantics of Sound and Speech in the Traditional Culture of the Slavs.] Moscow: Indrik, pp. 105-122. Available at http://inslav.ru/images/stories/ pdf/1999_mir_zvuchaschij_i_molchaschij.pdf, last accessed on 13 April 2018.

Sedakova, Irina 2007. Lingvokul'turnye osnovy rodinnogo teksta bolgar. [Linguo-Cultural Basics of Family Text of Bulgarians.] Extended summary of PhD thesis. Moscow: The Institute of Slavonic Studies. Available at http://www.ruthenia.ru/folklore/ sedakova2.htm, last accessed on 13 April 2018.

Shein, Pavel 1893. Materialy dlia izucheniia byta i iazyka russkogo naseleniia SeveroZapadnogo kraia. [Materials for Studying the Way of Life and Language of the Russian Population of the Northwestern Territory.] T. 2. St. Petersburg: Imperatorskaia Akademiia Nauk.

Strakhov, Aleksander 2005. Polesskiye fol'klorno-etnograficheskiye materialy v sovremennykh zapisyakh: 2. Zagovory i narodnaya meditsina. Publikatsiya i kommentarii A.B.Strakhova. [Polessye Folklore and Ethnographic Materials in Modern Records: 2. Charms and Folk Medicine. Publication and Comments by A.B. Strakhov.] Palaeoslavica, Vol. 13, No. 2, pp. 163-204.

Szukiewicz, Wandalin 1910. Niektóre wierzenia, pszesądy i zabobony ludu naszego, legendy i podania. [Some of the Beliefs, Prejudices and Superstitions of Our People, Legends and Traditions.] Kwartalnik Litewski, Vol. 2, pp. 85-102; Vol. 4, pp. 111-124.

Talko-Hryncewicz, Julian 1893. Zarysy lecznictwa ludowego na Rusi potudniowej. [Essays of Folk Medicine in Southern Russia.] Kraków: Nakładem Akademii Umiejętności.

Tolstoy, Nikita 2003. Ocherki slavyanskogo yazychestva. [Essays on Slavonic Paganism.] Moscow: Indrik. Available at http://inslav.ru/publication/tolstoy-n-i-ocherkislavyanskogo-yazychestva-m-2003, last accessed on 16 April 2018.

Tsyvjan, Tatiana 1982. Prostranstvo i vremya v balkanskikh okhranitel'nykh obryadakh, svyazannykh s rozhdeniyem rebenka. [Space and Time in the Balcan ChildbirthRelated Protection Rites.] Macedonian Folklore, Vol. 29-30, pp. 117-123.

Valodzina, Tatsiana 2004. Iz narodnoj miediciny bielorusov. [From the Folk Medicine of Belarusians.] Zhivaja Starina [Living Antiquity], No.1, pp. 37-38.

Vasilevich, U. (comp.) 1999. Ziamnaja daroha ŭ vyraj: Bielaruskija narodnyja prykmiety $i$ pavierji. In 3 vols. [The Earthly Road to the Paradise: Belarusian Folk Beliefs and Superstitions.] Minsk: Mastatskaya Litaratura.

Vinogradov, Georgiy 1915. Samovračjevanije i skotoliečjenije u russkoho starožiloho nasielienija Sibiri (Matierialy po narodnoj miedicinie i vietierinarii). Vostočnaja Sibiŕ, Tulunovskaja volost́, Nižjeudinskij ujezd, Irkutskaja hubiernija. [SelfTreatment and Animal Treatment by Russian Long-Standing Inhabitants of Siberia (Materials in Folk Medicine and Veterinary). Eastern Siberia, Tulunovsk Volost, Nizheudin Ujezd, Irkutsk Province.] Zhivaja Starina [Living Antiquity], Vol. 24, No. 4, pp. 325-432. Available at https://www.booksite.ru/jiv/1915_4.pdf, last accessed on 16 April 2018. 
Walczak-Mikołajczakowa, Mariola 2001. Batkańskie rytmy życia: Czyli o tradycji przechowanej $w$ języku. [Balkan Rhythms of Life: That Tradition is Hidden in the Language.] Gniezno: Gnieźnieńska Firma Wydawnicza "TUM”.

Wereńko, Frantiszek 1896. Przyczynek do lecznictwa ludowego. [Contribution to Folk Healing.] Materiaty antropotogiczno-archeotogiczne i etnograficzne. [Anthropological, Archaeological and eEhnographic Materials.] Vol. 1. Kraków: Nakladem Akademii Umiejetnos'ci, pp. 99-229.

Zadrożyńska, Anna \& Wrocławski, Krzysztof \& Vrazinowski, Tomas 2002. Ludowe obrzędy i podania: Etnograficzne i folklorystyczne studia porównawcze wsi polskiej $i$ macedonskiej. [Folk Rituals and Ideas: Ethnographic and Folklore Comparative Studies of the Polish and Macedonian Villages.] Warszawa: UW IEiAK.

Zahadki $1972=$ Zahadki. [Riddles.] Compiled by M.I. Hrynblat \& A.I. Hurski. Minsk: Navuka i Tekhnika. 